\title{
EFEK ANTI PROLIFERATIF EKSTRAK ETANOL KULIT BATANG \\ TANAMAN CANGKRING (Erythrina fusca Lour) \\ TERHADAP SEL MYELOMA
}

\author{
Edy Meiyanto*), Sismindari*), Asih Triastuti**) \\ *) Fakultas Farmasi Universitas Gadjah Mada Jogjakarta; ${ }^{* *}$ ) Jurusan Farmasi Universitas \\ Islam Indonesia Jogjakarta
}

\begin{abstract}
Erythrina fusca Lour has been traditionally used to cure hepatosis, malaria, hematuria, and cancer. The bark of this plant contains $\beta$ carotene, polifenol, thiamin, saponin, and alkaloid erythralin and erythramin. The aim of this research was to know the underlying mechanism of its effect as antiproliferative against Myeloma cells.

The bark powder was extracted using ethanol $(70 \%)$ and was used for the experiment after freezed drying. Citotoxicity test of this extract performed LC50 of $0,367 \mathrm{mg} / \mathrm{ml}$. The rate of proliferation was observed by doubling time effect against proliferating cells. The cells were exposed with ethanolic extract in RPMI 1640 medium containing 1) $0,25 \mathrm{mg} / \mathrm{ml}$ 2) $6,25 \times 10^{-2} \mathrm{mg} / \mathrm{ml}$, and 3) $1,56 \times 10^{-2} \mathrm{mg} / \mathrm{ml}$ and every $0,6,12,24,48$, and 72 hours cell were counted. The result showed that extract treated cells delayed proliferation at all concentration with doubling time dose 2) of 161, 38 hours, and dose 3 ) of 93,91 hours, whereas doubling time of control cells were 69,86 hours. Ethidium bromide staining of extract treated cells showed apoptosis like profile.

These results indicated that ethanolic extract of the bark of Erythrina fusca Lour has an antiproliverative effect on Myeloma cell line. Several mechanisms might account for this effect, like inhibiting cell cycle progression, signal transduction, causing delayed and apoptosis
\end{abstract}

Keywords: Erythrina fusca Lour, atiproliferative, Myeloma

\section{PENDAHULUAN}

Kanker merupakan the outlaw cell karena telah kehilangan regulator proliferasi (onkogen, gen tumor supresor dan mismatch repair gene) dan homeostatis (Hanahan and Weinberg, 2000). Kanker merupakan penyebab dari $12 \%$ kematian di dunia, dan di negara barat dan Amerika Serikat kanker merupakan penyebab kematian kedua setelah penyakit jantung (Anonim, 2000; King, 2000). Salah satu strategi untuk pengembangan obat kanker adalah dengan menemukan senyawa-senyawa yang mendasarkan target aksinya pada gen-gen pengatur pertumbuhan, yaitu onkogen yang berfungsi sebagai pemacu perkembangan sel dan gen tumor supresor sebagai penghambat perkembangan sel. Telah banyak dilaporkan bahwa bahan dari tanaman (active ingredient) memiliki potensi sebagai regulator negatif dari onkogen dan regulator positip dari gen tumor suppressor sehingga berpotensi sebagai anti kanker (Cassady, 1990). Penelitian terhadap beberapa tumbuhan yang termasuk dalam genus Erythrina menunjukkan aktivitasnya sebagai inhibitor cyclooxigenase (COX II) dan anti inflamasi (Pillay et al, 2001). Aktivitas tersebut memberikan makna positip sebagai anti tumor karena perkembangan tumor seringkali melibatkan enzim cyclooxigenase (Dubois et al, 1998). Erythrina fusca secara empiris telah digunakan untuk mengobati gabag, cacar air, hepatosis bisul, dan kanker (Heyne, 1987; Hartwel, 1967-1971). Ekstrak air daunnya mengandung RIP tipe 2 dan mampu menghambat pertumbuhan sel HeLa (Julia, 2000) dan myeloma (Handayani, 2001) dan ekstrak metanol daunnya mampu menghambat enzim Topoisomerase II (Sismindari et al, 2001). 
Dengan uraian di atas akan diteliti apakah ekstrak etanol dari Erythrina fusca Lour memiliki aktivitas antiproliferasi terhadap sel myeloma sebagai model sel kanker.

\section{METODOLOGI PENELITIAN}

\section{Bahan}

Kulit batang Erythrina fusca Lour diambil dari daerah Moyudan, Yogyakarta pada bulan Nopember 2001 kemudian diidentifikasi di Laboratorium Biologi Farmasi Fakultas Farmasi UGM, Myeloma cell line diambil dari stok Laboratorium Hayati UGM.

\section{Alat}

Seperangkat alat kultur sel (Nunclon), inkubator $\mathrm{CO}_{2}$ (Heraeus), Laminar Air Flow, Hemocytometer (Nebaeur), cell counter, mikroskop fluoresens (Olympus), mikroskop inverted (Olympus) dan seperangkat alat untuk KLT.

\section{Cara Penelitian}

\section{Preparasi ekstrak}

Kulit batang tanaman dibersihkan dan dikeringkan dalam oven pada suhu $70^{\circ} \mathrm{C}$. Setelah kering simplisia diblender hingga menjadi serbuk. Ekstrak alkohol diperoleh dengan cara ekstraksi dalam pelarut etanol $80 \%$ dengan labu soxhlet. Selanjutnya ekstrak diuapkan sampai kering dalam aliran udara (freeze drying).

\section{Uji sitotoksisitas}

Ekstrak etanol dilarutkan dalam 1,25\% DMSO dalam aquabides steril, disaring dengan filter 0,2 $\mu \mathrm{m}$, dan selanjutnya dibuat seri kadar ekstrak dari larutan stock dalam media RPMI. Ekstrak $100 \mu \mathrm{l}$ dalam media kultur RPMI 1640 dengan suatu konsentrasi $1 \mathrm{mg} / \mathrm{ml} ; 0,25 \mathrm{mg} / \mathrm{ml} ; 6,25 \times 10^{-2} \mathrm{mg} / \mathrm{ml} ; 1,5625 \times 10^{-2} \mathrm{mg} / \mathrm{ml}$; $3,906 \times 10^{-3} \mathrm{mg} / \mathrm{ml} ; 9,77 \times 10^{-4} \mathrm{mg} / \mathrm{ml}$, masing-masing dimasukkan dalam 96 sumuran berbeda. Selanjutnya ditambahkan $100 \mu \mathrm{l}$ suspensi sel pada tiap sumuran (kepadatan sel $5 \times 10^{4} \mathrm{sel} / \mathrm{sumuran}$ ). Plate diinkubasi dalam inkubator $\mathrm{CO}_{2} 5 \%$ selama 24 jam pada suhu $37^{\circ} \mathrm{C}$. Setelah itu tiap sumuran diresuspensi, ditambahkan $50 \mu \mathrm{l}$ biru tripan, diambil $10 \mu \mathrm{l}$ dan dihitung jumlah selnya menggunakan hemocytometer.

\section{Uji doubling time}

Sel distarvasi selama 24 jam dalam media kultur yang mengandung FBS $0,5 \%$ (Meiyanto et al, 2001), selanjutnya sel ditumbuhkan di dalam plate dengan medium yang ditambah ekstrak dengan seri kadar $0,25 \mathrm{mg} / \mathrm{ml} ; 6,25 \times 10^{-2} \mathrm{mg} / \mathrm{ml}$ dan $1,5625 \times 10^{-2} \mathrm{mg} / \mathrm{ml}$, sampling dilakukan pada jam ke $0,6,12,24$, 48, dan 72. Masing-masing sampel sel dihitung dengan hemocytometer kemudian dibuat kurva jumlah sel vs waktu inkubasi (Field et al, 1996). Pada jam ke 48 dilakukan pengecatan DNA dimana sel sel dalam sumuran diresuspensi, diambil $10 \mu \mathrm{l}$, difiksasi dengan metanol, ditambahkan RNAase dan ditambahkan etidium bromide, diinkubasi 30 menit pada suhu kamar dan diamati di bawah mikroskop fluoresens.

\section{HASIL DAN PEMBAHASAN}

Dari hasil pemeriksaan kandungan kimia dengan KLT, ekstrak etanol mengandung senyawa flavonoid, alkaloid, saponin, dan terpenoid. Uji kesitotoksikan terhadap sel myeloma dilakukan untuk mengetahui potensi ketoksikan ekstrak etanol dan digunakan sebagai dasar untuk penentuan dosis pada uji doubling time. Parameter yang digunakan adalah $\mathrm{LC}_{50}$ yang merupakan implementasi potensi ketoksikan (Hodgson and Levi, 2000). Analisa LC 50 dilakukan dengan analisa probit (Mursyidi, 1985) dan didapatkan harga $\mathrm{LC}_{50} 0,367 \mathrm{mg} / \mathrm{ml}$. 
Tabel I dan gambar 1 memperlihatkan semakin besar kadar ekstrak maka semakin besar pula persentase kematian sel myeloma. Pada blanko (perlakuan dengan DMSO) tidak mempengaruhi pertumbuhan sel myeloma.

Tabel I. Hasil uji sitotoksisitas

\begin{tabular}{|c|c|c|}
\hline \multirow{2}{*}{ Kadar $(\mathrm{mg} / \mathrm{ml})$} & \multicolumn{2}{|c|}{ Persentase kematian (\%) } \\
\cline { 2 - 3 } & Ekstrak etanol & Blanko (DMSO) \\
\hline 0,00098 & $10,98 \pm 10,29$ & $24,39 \pm 7,05$ \\
\hline 0,0039 & $16,98 \pm 17,32$ & $24,11 \pm 3,22$ \\
\hline 0,016 & $25,63 \pm 2,30$ & $20,97 \pm 2,83$ \\
\hline 0,0625 & $37,42 \pm 3,74$ & $25,82 \pm 8,88$ \\
\hline 0,25 & $40,09 \pm 4,00$ & $23,54 \pm 3,23$ \\
\hline 1 & $78,89 \pm 9,50$ & $8,42 \pm 4,43$ \\
\hline
\end{tabular}

Uji sitotoksisitas ini belum dapat menerangkan mekanisme kematian sel secara jelas/ pasti. Pada kadar di atas $0,5 \mathrm{mg} / \mathrm{ml}$, kemungkinan ekstrak dalam jumlah besar keberadaannya mengganggu di dalam pengambilan nutrisi oleh sel sehingga menyebabkan kematian sel. Pada kadar rendah, yaitu di bawah $0,5 \mathrm{mg} / \mathrm{ml}$ kemungkinan ada mekanisme molekuler yang terlibat dalam proses kematian sel myeloma.

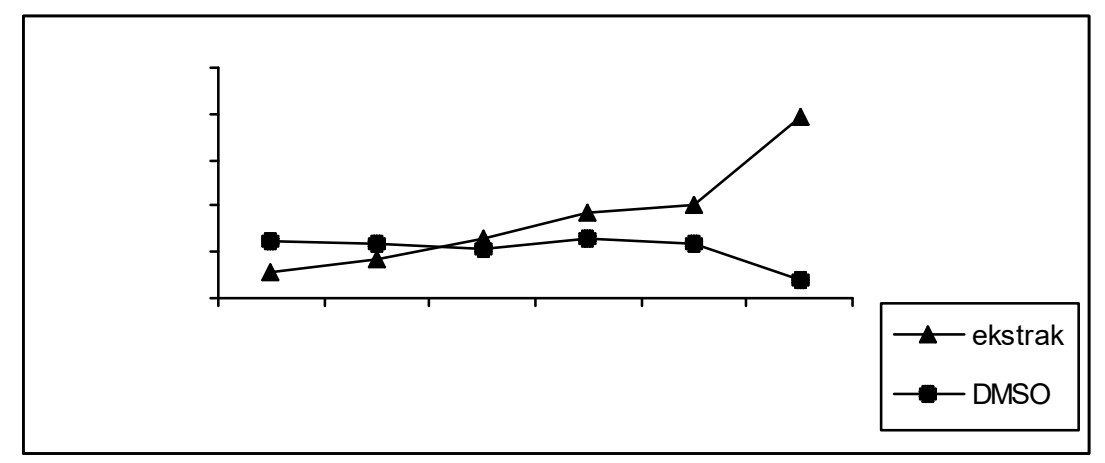

Gambar 1. Hasil uji Sitotoksisitas menunjukkan adanya penurunan persentase kematian sel dengan semakin menurunnya kadar ekstrak.

Selain mengamati jumlah sel yang merupakan implementasi persentase kematian sel, juga bisa dilihat dari gambaran morfologi sel myeloma secara mikroskopis (gambar 2) yang memperlihatkan efek sitotoksik dari ekstrak etanol.

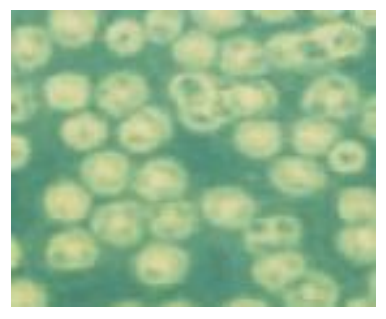

A

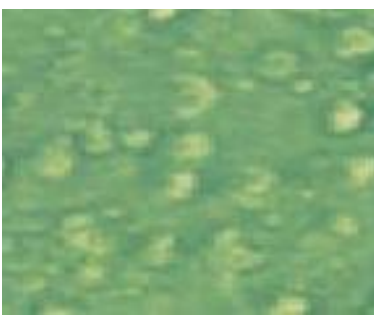

B

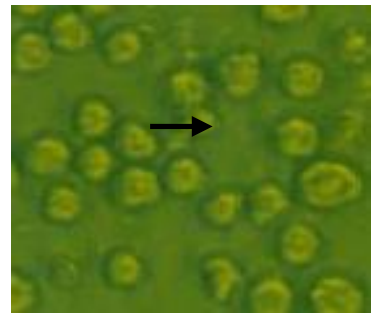

C 
Sel pada kontrol

(tanpa perlakuan)
Sel pada blanko

(perlakuan dengan DMSO)
Sel pada perlakuan dengan ekstrak kadar $0,25 \mathrm{mg} / \mathrm{ml}$

Gambar 2. Foto mikroskopik sel myeloma pada uji sitotoksisitas, tampak pada kontrol dan blanko terlihat bentuk sel bulat, dengan inti di tengah menandakan sel hidup sedangkan pada perlakuan dengan ekstrak terlihat sel mati dan lisis.(tanda panah)

Kemungkinan komponen dari ekstrak etanol mampu memacu sel untuk melakukan apoptosis ataupun membuat sel nekrosis. Untuk mengetahui mekanisme molekuler ini maka penelitian dilanjutkan dengan uji doubling time untuk mengetahui efek pemberian ekstrak etanol terhadap cell cycle progression dari sel myeloma.

Uji doubling time dilakukan di bawah kadar $\mathrm{LC}_{50}$ yaitu kadar 1) $0,25 \mathrm{mg} / \mathrm{ml}$,2) $6,25 \times 10^{-2} \mathrm{mg} / \mathrm{ml}$, dan kadar 3) $1,56 \times 10^{-2} \mathrm{mg} / \mathrm{ml}$. Uji yang dilakukan memperlihatkan bahwa jumlah sel antara kontrol (tanpa perlakuan) dan perlakuan dengan ekstrak menunjukkan perbedaan yang bermakna $(p=0,05)$.

Mekanisme penghambatan pertumbuhan ini kemungkinan dengan mempengaruhi cell cycle progression, signal transduksi, atau bahkan memacu apoptosis dari sel myeloma. Pada ekstrak kadar $6,25 \times 10^{-2}$ $\mathrm{mg} / \mathrm{ml}$; dan kadar $1,56 \times 10^{-2} \mathrm{mg} / \mathrm{ml}$ terlihat penghambatan pertumbuhan sel yang mengindikasikan adanya penundaan waktu penggandaan sel (Gambar 3). Perhitungan doubling time sel, pada kontrol didapatkan harga 69,86 jam sedangkan pada perlakuan dengan ekstrak sebesar 161,38 jam pada kadar $6,25 \times 10^{-2} \mathrm{mg} / \mathrm{ml}$; dan pada kadar $1,56 \times 10^{-2} \mathrm{mg} / \mathrm{ml}$ 93,91 jam (Gambar 4)

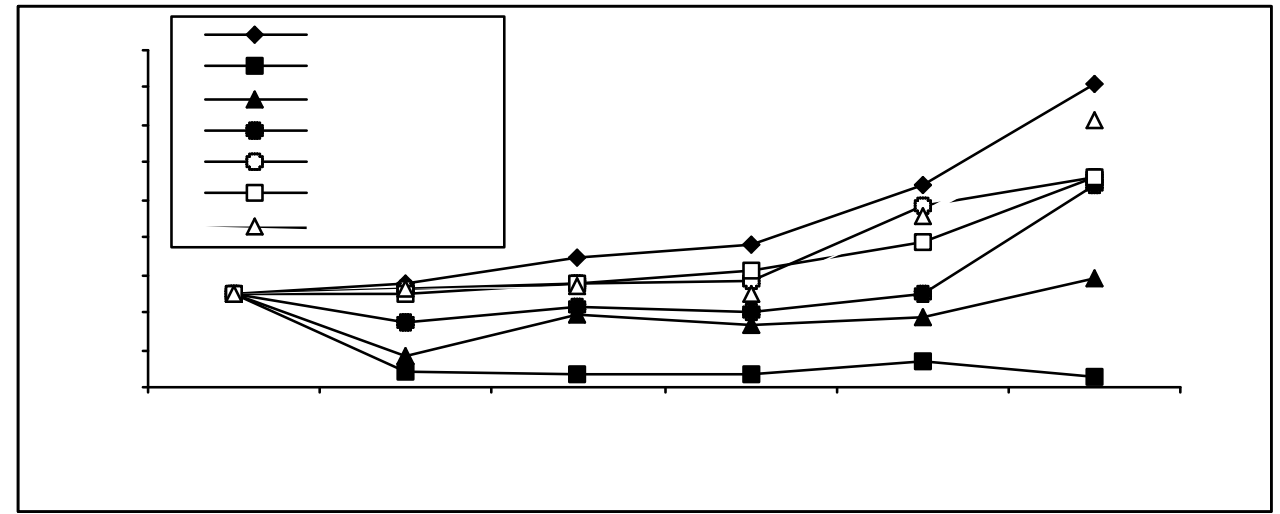

Gambar 3 . Hasil uji doubling time pada kadar 1) 0,25 mg/ml; kadar 2) $6,25 \times 10^{-2} \mathrm{mg} / \mathrm{ml}$; dan kadar 3) $1,56 \times 10^{-2}$ $\mathrm{mg} / \mathrm{ml}$. 


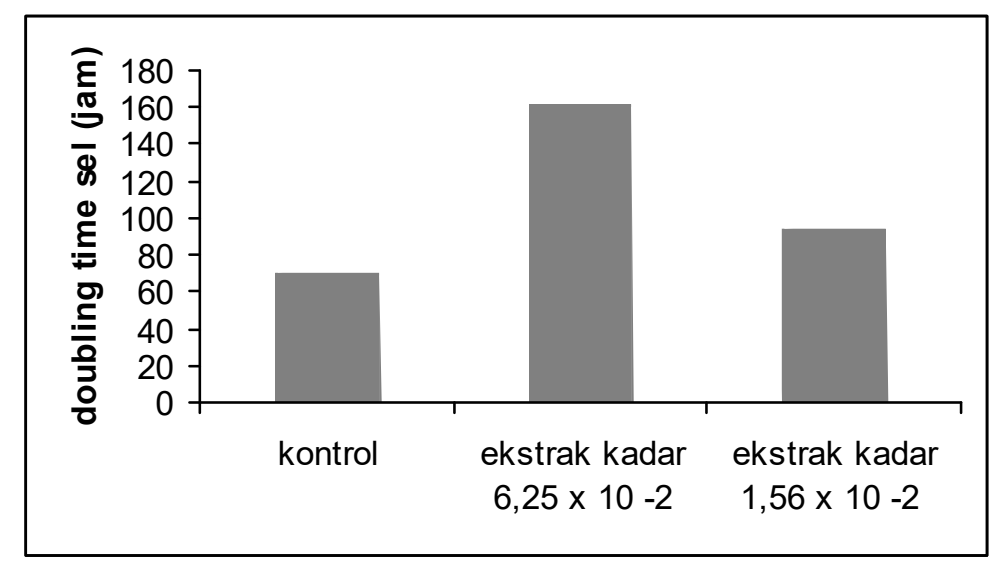

Gambar 4. Hasil uji doubling time. Waktu penggandaan sel pada perlakuan dengan ekstrak lebih besar dibandingkan dengan kontrol yang menunjukkan adanya penghambatan langsung pada proses cell cycle progression. Semakin rendah kadar ekstrak, kemmapuan penghambatan pada cell cycle makin kecil.

Cell cycle progression merupakan parameter utama dalam mengukur sifat proliferatif sel. Cell cycle diawali oleh adanya signal pertumbuhan yang diteruskan hingga ke nukleus yang akan menginisiasi faktor transkripsi untuk mentranskrip gen-gen yang diperlukan untuk pembelahan sel, termasuk gen-gen regulator cell cycle seperti cyclin dan cyclin dependent kinase (Cdk) (Weinberg, 1996). Banyak komponen yang diuji sebagai anti tumor mempengaruhi cell cycle progression dan menginduksi cell arrest dengan mekanisme multi tahap (Shapiro and Harper, 1999).

Proses signal transduksi melibatkan beraneka ragam protein yang menjalankan fungsi sesuai dengan signal yang diterimanya. Umumnya signal transduksi yang mengarah pada cell cycle progression melibatkan banyak jenis protein kinase, misalnya PKC. Signal tersebut merupakan signal yang mengaktivasi downstream effector yang melibatkan proses fosforilasi dengan memanfaatkan ATP (Gibbs, 2000). Proses ini dapat dihambat oloeh senyawa-senyawa alam dari jenis flavonoid, steroid, dan produk mikrobia (Cardenas, 1998).

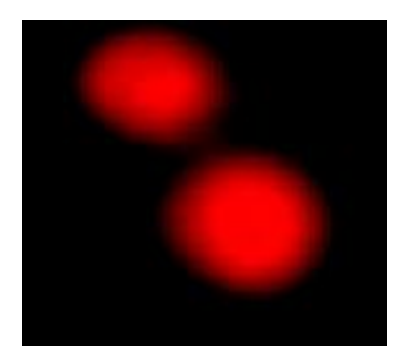

A

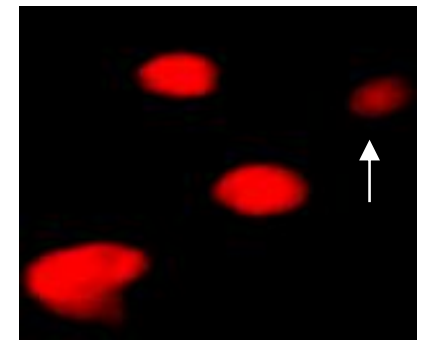

B

Gambar 5. Hasil pengamatan morfologi sel dengan mikroskop fluoresens setelah dilakukan pengecatan dengan Etidium bromida. Sel tanpa perlakuan terlihat bulat dan besar (A) dengan perlakuan ekstrak (B) memperlihatkan adanya potongan sel yang kecil (tanda panah) mendakan adanya fenomena apoptosis.

Dari hasil uji kandungan kimia dengan KLT ekstrak etanol E. fusca mengandung senyawa-senyawa flavonoid, alkaloid, terpenoid, dan saponin. Kemungkinan komponen dari ekstrak etanol $E$. fusca mampu mempengaruhi cell cycle progression dari sel myeloma. Selain itu kemungkinan ekstrak etanol juga mampu mempengaruhi signal transduksi pada sel yang mana komponen ekstrak bisa mempengaruhi protein-protein yang terlibat dalam proses penerusan signal. Selain itu ekstrak etanol 
kemungkinan juga bisa memacu sel untuk melakukan program bunuh diri (apoptosis) seperti terlihat pada gambar 5. Pada kontrol terlihat DNA yang bulat menandakan sel yang masih hidup, dan pada perlakuan dengan ekstrak terlihat DNA terpotong yang mengindikasikan terjadinya apoptosis.

\section{KESIMPULAN}

Ekstrak etanol kulit batang tanaman cangkring Erythrina fusca Lour memiliki aktivitas anti proliferasi terhadap sel myeloma yang menunjukkan fenomena ketergantungan dosis.

\section{UCAPAN TERIMAKASIH}

Ucapan terimakasih disampaikan kepada QUE project Fakultas Farmasi Universitas Gadjah Mada yang telah membiayai penelitian ini.

\section{DAFTAR PUSTAKA}

Albert, B., Bray, D., Lewis, J., Roberts, K., and Watson, J.D., 1994, Molecular Biology of the Cell, Thid Ed. Garland Publ Inc., NY, 1255, 1269, 1270, 1282, 1283.

Anonim, 2000, Cancer insidence, Mortality and Prevalence Worldwide (2000 estimates), available at : http://www-dep.iarc.fr/dataava/infodata.htm, 2001

Backer, C.A., and Bakhulzen van den Brink, R.C., 1965, Flora of Java, Spermatophytes Only, Vol I, N.V.P. Moordhoff-Gronigen-The Netherlands.

Cardenas, M.E., Sanfridson, A., Cutler, N.S., Heitman, J., 1996, Signal transduction cascades as targets for theurapetic intevention by natural products, TIBTECH, 16:427-433

Cassady, J.M., 1990, Natural product as a source of potential cancer chemotherapeutic and chemopreventive agents, Journal of Natural Produts, 53: 23-41

Dubois, R.N., Abramson, S.B., Crofford, L., Gupta, R.A., Simon, L.S., Van De Putte, L.B., and Lipsky, P.E., 1998, Cyclooxigenase in Biology and Disease, FASEB J, 12 : 1063-1073

Field, S.J., Tsai, F.Y., Kuo, F, Zubiaga, A.M., Kaelin, W.G., Livingstone D.M., Orkin, S.H., and Greenberg, M.E., 1996, E2F-1 functions in mice to promote apoptosis and suppress proliferation, Cell, 17: 549-561 
Gibbs, J.B., 2000, Anticancer drug targets: growth factor and growth factor signaling, J.Clin.Invest, 105:9-13

Hanahan D. And Weinberg, R.A., 2000, The Hallmark of Cancer, Cell, 100: 57-70

Handayani, A.S., 2001, Uji Sitotoksiistas Fraksi Protein Daun Erythrina fusca Lour (Cangkring) trhadap sel myeloma, Skripsi, Fakultas Farmasi Universitas Gadjah Mada, Yogyakarta.

Hatrwell, J.L., 1967-1971, Plant Used Against Cancer, A Survey, Lioydia, 30-34

Heyne, K., 1987, Tumbuhan Berguna Indonesia, diterjemahkan oleh Badan Litbang Kehutanan Jakarta, Jilid II, Ed. I, Badan Litbang Kehutanan, Jakarta.

Hodgson, E. and Levi, P., 2000, A Textbook of Modern Toxicology, Second Ed., McGraw-Hill Companies Inc, Singapore, 292-294

Julia, S., Uji Sitotoksisitas Fraksi Protein Daun Erythrina fusca Lour (Cangkring) pada sel Hela, Skripsi, Fakultas Farmasi Universitas Gadjah Mada, Yogyakarta.

King, R.J.B., 2000, Cancer Biology, Second Ed., Pearson Education Ltd, London, 157-173

Meiyanto,E., Hosijima, M., Ogawa, T., Ishida, N., and Takeya, T., 2001, Osteoclast Diffeentiation Factor Modulates Cell Cycle Machinery and Causes a Delay in S phase Progression in RAW264 Cells, Biochemical and Biophysical Research Communication, 282: 278-283

Mursyidi, A., 1985, Statistika Farmasi dan Biologi, Ghalia Indonesia, Jakarta, 61, 157

Pillay, C.C.N., Jager, A.K., Mulholland, D.A., van Staden, J., 2001, Cyclooxigenase inhibiting and antibactrial activities of South African Erythrina species, Journal of Ethnopharmacology, 74(3) : 231-237

Shapiro, G.I. and Harper, J.W., 1999, Anticancer drug target: cell cycle and checkpoints control, J. Clin. Invest, 104: 1645-1653

Sismindari, Yuswanto, Ag., Susanti, L., dan Ngolady, D., 2001, Effect of aqueous and methanol extract of Erythriuna fusca's Lour on DNA Topoisomerase II, J. Protech, submitted 